\title{
Análisis epidemiológico retrospectivo de Distemper Canino en la ciudad de Pachuca de Soto, Estado de Hidalgo
}

\section{Retrospective epidemiological analysis of Canine Distemper in Pachuca of Soto city, Hidalgo State}

Rebollar-Zamorano Maleny, Morales-Ubaldo Ana L, González-Alamilla Eddy N, Ángeles-Rodríguez Adán, Valladares-Carranza Benjamín, Velásquez-Ordoñez Valente, Rivero-Pérez Nallely*, Zaragoza-Bastida Adrián*

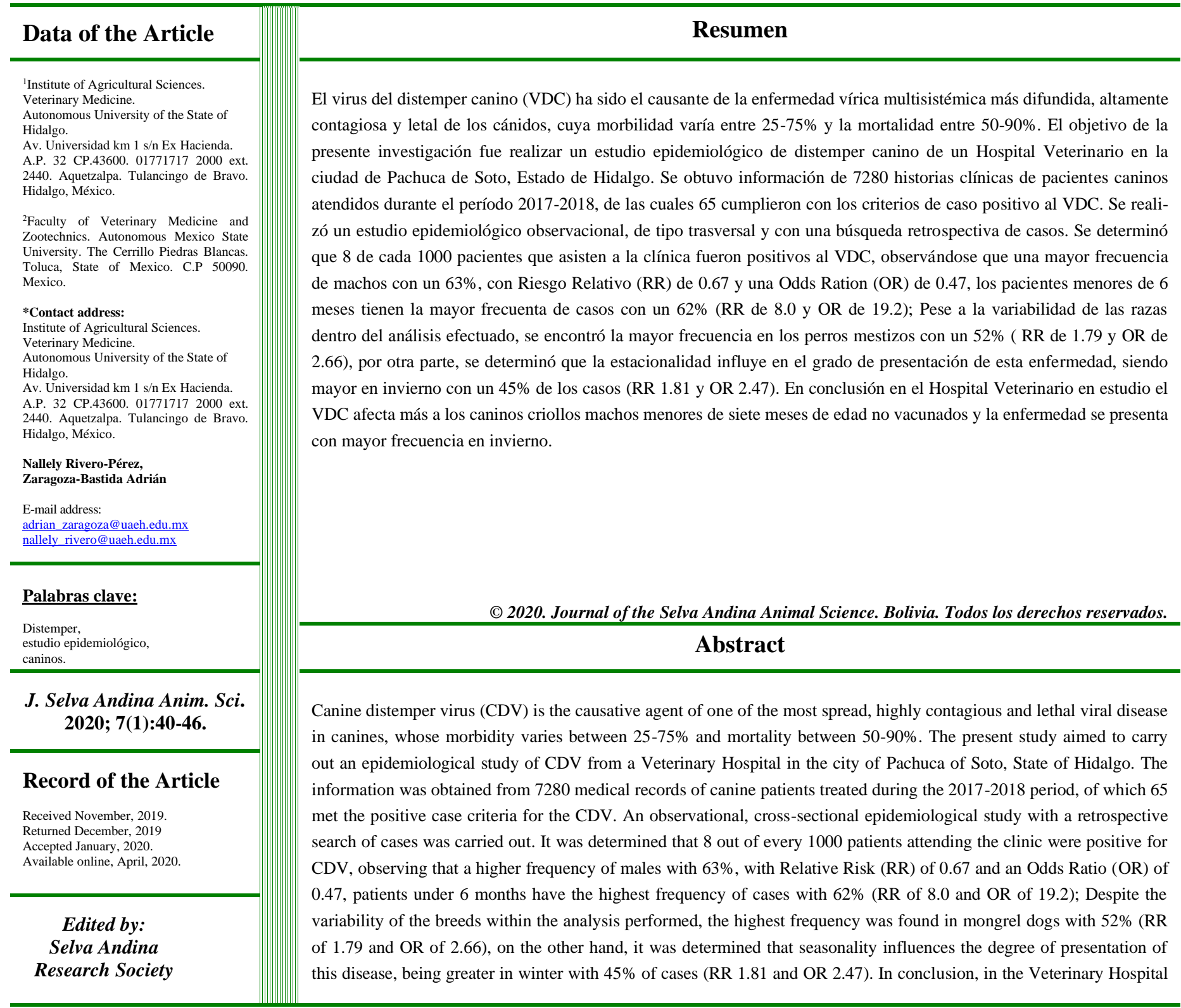




\begin{tabular}{l|||l|l}
\hline Key words: & $\begin{array}{l}\text { understudy, the CDV affects male Creole dogs less than seven months of age unvaccinated more and the disease occurs } \\
\text { most frequently in winter. }\end{array}$ \\
$\begin{array}{l}\text { Distemper, } \\
\text { epidemiological study, } \\
\text { canines. }\end{array}$ & O 2020. Journal of the Selva Andina Animal Science. Bolivia. All rights reserved. \\
\hline
\end{tabular}

\section{Introducción}

Canine Distemper Virus (CDV) also known as distemper or Carré as discovered by Henri Carré in 1905 , this virus has been the cause of the most widespread, highly contagious and lethal multisystemic viral disease of canids and other members of the Procyonidae and Mustelidae families ${ }^{1}$, it is a disease of high morbidity and variable mortality ${ }^{2}$. The virus belongs to the family Paramyxoviridae of the genus Morbillivirus, the infection in dogs can lead to severe multisystemic disease, which affects the gastrointestinal, respiratory, and neurological systems ${ }^{3}$.

Viral replication produces cellular destruction, which clinically results in vomiting, diarrhea, bronchitis, pneumonia, dermatitis, and behavioral disturbances, including neurological manifestations such as myoclonus, spasms, paresis, skin hyperesthesia, and seizures ${ }^{4}$. Consequently it doesn't exist effective antiviral treatment, it is nonspecific and palliative.

Therapeutic actions are symptomatic and supportive, aimed at limiting secondary bacterial infections via using broad-spectrum antibiotics, maintaining fluid balance, and in the case of respiratory disturbances, expectorants, and brochodilators ${ }^{5}$.

From a public health point of view, it is believed that CDV doesn't infect human cells or causes diseases in humans, nevertheless, some studies have found that said virus has taken place in Piaget bone disease $^{6}$, in the same way, it has been shown that the virus infects and replicates in human osteoclast precursors, increasing concern about the possibility of zoonotic transmission of $\mathrm{CDV}^{7}$.

According to with a study carried out by Costa in $2019^{8}$, in Mexico until 2018 there is no report of studies carried out in the country, regarding the prevalence of CDV, therefore in Pachuca city and the rest of Hidalgo State, the study of this disease is null, mainly due to the lack of analysis of the information that is collected in veterinary consultations, this limitation is attributed to the lack of an adequate experimental design to address the problem.

Due to the aforementioned, the present investigation is aimed to carry out an epidemiological study of Canine Distemper Virus in a veterinary hospital (VH) in the city of Pachuca de Soto, belonging to Hidalgo State.

\section{Material and methods}

Study área. The study was carried out in the veterinary Hospital "Petterra", located in Pachuca de Soto city, capital of Hidalgo State. The city is geographically located between the coordinates $20^{\circ}, 07$ 'and $21^{\prime \prime}$ north and $98^{\circ}, 44$ '09" west longitude, with a height of 2400 to 2800 masl. The city is bordered to the north by Mineral del Chico and Mineral del Monte, to the south by Zempoala and Zapotlán de Juárez, to the east by Mineral de la Reforma and Epazoyucan, and to the west by San Agustín Tlaxiaca. The climate is temperate semi-cold, with rains in summer, its rainfall from 400 to $800 \mathrm{~mm}$ 
annually. The prevailing winds occur 9 months a year and generally come from the northeast, having an extreme speed of 60 to $65 \mathrm{~km} / \mathrm{h}$. Its annual average temperature is $24^{\circ} \mathrm{C}$.

Sampling unit. A search was carried out in the medical records archives of the canine patients admitted and attended in general consultation at the $\mathrm{VH}$ during the period 2017-2018. The clinical diagnosis of CDV was performed considering the clinical signs and manifestations, which the patient evidenced during the general clinical examination, such as appetite loss, depression, hyperthermia or fever, ocular and nasal discharge, conjunctivitis, neurological signs, and pads hyperkeratosis (palmar and plantar) and in the nasal plane. The clinical diagnosis of CDV cases was confirmed by laboratory analysis (biometrics) and rapid tests (Test Kit Materlab $\left.{ }^{9}\right)$.

Inclusion and exclusion criteria. Any canine with clinical sinology and biometrics associated with $\mathrm{CDV}$ was considered as a positive case, as well as those confirmed by rapid tests (Test Kit Materlab ${ }^{9}$ ). Respect to the age, those canines younger than two months, with nervous signs during admission or with presumptive clinical manifestations of another pathology, and were receiving any pharmacological treatment, were excluded.

Study design. It was carried out a non-experimental, descriptive, cross-sectional epidemiological study (period 2017-2018) with a retrospective case search. The study cases $(n=65)$ and the reference population(7280) were tabulated in electronic spreadsheets from Microsoft Excel® software, considering gender, vaccination history, age, same which was stratified into age groups: less than or equal at 6 months (puppies), from 7 to 12 months (puberty), from 13 to 36 months (adults), from 37 to 72 months (mature) and animals older than 72 months (senile), respect to the breed, only the breeds with more than three cases were tabulated, breeds with only one case were considered in other breeds and seasonality (date of medical history). CDV cases were compared to canines attended for some different CDV reasons in the same study period.

Statistical analysis. Once data was obtained, a descriptive statistical analysis was performed, the information was represented in tables and figures, the effect of the variables aforementioned was analyzed over the disease presence, through a casecontrol design, it was calculated relative risk (RR), Odds ratio (OR) and Chi-Square test $\left(X^{2}\right)$, calculations were carried out in the statistical package EPIDAT $3.1^{10}$.

\section{Results}

During the period 2017-2018, it was diagnosed 65 positive CDV cases, representing a prevalence rate of 9 cases for every 1000 patients who attend the VH under study. Respect to the association of the studied variables and the relation with the disease presence it was determined, that males are the most affected with $63 \%$ (41 of 65 ) compared to females with $37 \%$ (24 of 65), a statistically significant association $(\mathrm{P}=0.034)$ was observed for this variable, with a RR of 0.67 and 0.46 (OR) more possibilities to acquire CDV in the case of males (table 1).

Regarding vaccination history, is important to highlight that $65 \%$ of the cases under study was not vaccinated (40 of 65 ), it was determined a statistically significant association $(\mathrm{P}=0.003)$ respect to the patients which was not vaccinated and the presence of CDV, patients without vaccination history had a RR (2.50) and 3.44 (OR) more times the possibility of contracting the disease (table 1 ).

The first six months of life ( $\leq 6$ months), is the age at which $62 \%$ (40 of 65 ) of patients contract the 
virus, it was determined that the patient's age is statistically associated $(\mathrm{P}=0.0001)$ with the presence of the disease, observing a descent of the RR and the OR according to the age of patients increase, nevertheless the age group with patients under six months is the most affected with a RR of 8 , significantly higher than that of the other considered age groups, and 19 (OR) more times the possi- bility to contract the disease at this age (table 2). However it was determined a statistically significant association in the group of adult patients $(\mathrm{P}=0.014)$ and senile $(\mathrm{P}=0.008)$, noticing that the $\mathrm{RR}$ and $\mathrm{OR}$ for these groups are less compared with the group above described (table 2).

Table 1 Gender and vaccination association with the presence of Canine Distemper virus in Pachuca of Soto City, Hidalgo State

\begin{tabular}{cccccccccccc}
\hline \multicolumn{2}{c}{ Factor } & Number of cases & $\mathbf{\%}$ & \multicolumn{1}{c}{ RR } & CI 95\% & OR & CI 95\% & $\boldsymbol{X}^{\mathbf{2}}$ & $\boldsymbol{P}$-value \\
\hline \multirow{2}{*}{ Gender } & Female & 24 & 37 & 0.67 & 0.45 & 0.98 & 0.47 & 0.23 & 0.95 & 4.46 & $0.034 *$ \\
& Male & 41 & 63 & & & & & & & & \\
\multirow{2}{*}{ Vaccinated } & yes & 25 & 39 & 2.50 & 1.31 & 4.78 & 3.44 & 7.95 & 3.31 & 8.80 & $0.003 *$ \\
& No & 40 & 61 & & & & & & & & \\
\hline
\end{tabular}

Tabla 2 Age association with with the presence of Canine Distemper virus in Pachuca of Soto City, Hidalgo State

\begin{tabular}{|c|c|c|c|c|c|c|c|c|c|c|}
\hline Age (months) & Number of cases & $\%$ & \multicolumn{2}{|c|}{$\mathbf{R R}$} & \multirow{2}{*}{$\begin{array}{r}\text { CI 95\% } \\
18.98\end{array}$} & \multirow{2}{*}{$\begin{array}{l}\text { OR } \\
19.2\end{array}$} & \multicolumn{2}{|c|}{ CI $95 \%$} & $X^{2}$ & \multirow{2}{*}{$\frac{\boldsymbol{P} \text {-value }}{0.000^{*}}$} \\
\hline$\leq 6$ & 40 & 62 & 8.00 & 3.37 & & & 6.78 & 54.33 & 41.63 & \\
\hline $7-12$ & 6 & 9 & 0.75 & 0.28 & 2.04 & 0.72 & 0.24 & 2.22 & 0.32 & 0.577 \\
\hline $13-36$ & 12 & 18 & 0.52 & 0.28 & 0.96 & 0.41 & 0.18 & 0.93 & 3.27 & 0.070 \\
\hline $37-72$ & 5 & 8 & 0.33 & 0.13 & 0.86 & 0.28 & 0.09 & 0.82 & 5.91 & $0.015^{*}$ \\
\hline$>72$ & 2 & 3 & 0.18 & 0.04 & 0.79 & 0.16 & 0.03 & 0.73 & 6.92 & $0.008 *$ \\
\hline
\end{tabular}

Table 3 Breed association with with the presence of Canine Distemper virus in Pachuca of Soto City, Hidalgo State

\begin{tabular}{lcccccccccc}
\hline \multicolumn{1}{c}{ Breed } & Number of cases & $\boldsymbol{\%}$ & \multicolumn{1}{c}{ RR } & \multicolumn{1}{c}{ CI 95\% } & OR & \multicolumn{1}{c}{ CI 95\% } & $\boldsymbol{X}^{\mathbf{2}}$ & $\boldsymbol{P}$-value \\
\hline Mestizo & 34 & 52 & 1.79 & 1.15 & 2.79 & 2.66 & 1.29 & 5.47 & 7.52 & $0.0061^{*}$ \\
Chihuahua & 5 & 8 & 0.63 & 0.22 & 1.81 & 0.59 & 0.18 & 1.92 & 0.77 & 0.3805 \\
German Shepherd & 4 & 6 & 0.57 & 0.18 & 1.86 & 0.54 & 0.15 & 1.95 & 0.84 & 0.3583 \\
Siberian Husky & 3 & 5 & 0.75 & 0.17 & 3.22 & 0.74 & 0.16 & 3.44 & 0.15 & 0.6976 \\
Pug & 3 & 5 & 0.75 & 0.17 & 3.22 & 0.74 & 0.16 & 3.44 & 0.14 & 0.7131 \\
Others & 16 & 25 & 2.00 & 0.92 & 4.35 & 2.33 & 0.92 & 5.90 & 3.27 & 0.0705 \\
\hline \multicolumn{1}{c}{ RR relative risk, CI confidence interval 95\%, OR Odds ratio, * Statistically significant value to 95\% } & & & &
\end{tabular}

Table 4 Season year effect over the presence of Canine Distemper virus in Pachuca of Soto City, Hidalgo State

\begin{tabular}{ccccccccccc}
\hline Season year & Number of cases & $\boldsymbol{\%}$ & \multicolumn{2}{c}{ RR } & \multicolumn{1}{c}{ CI 95\% } & OR & CI 95\% & $\boldsymbol{X}^{\mathbf{2}}$ & \multicolumn{1}{c}{$\boldsymbol{P}$-value } \\
\hline Winter & 29 & 45 & 1.81 & 1.09 & 3.00 & 2.47 & 1.17 & 5.21 & 5.74 & $0.0165^{*}$ \\
Spring & 15 & 23 & 0.94 & 0.51 & 1.73 & 0.92 & 0.41 & 2.06 & 0.04 & 0.8369 \\
Summer & 12 & 18 & 0.75 & 0.93 & 1.46 & 0.69 & 0.30 & 1.61 & 0.73 & 0.3934 \\
Fall & 9 & 14 & 0.56 & 0.27 & 1.18 & 0.49 & 0.20 & 1.21 & 2.43 & 0.1193 \\
\hline RR relative risk, CI confidence interval 95\%, OR Odds ratio * Statisticlly significat value to 95\%
\end{tabular}

43 
It was determined that $52 \%$ of CDV cases occurred in mestizo breed (34 of 65 ) and $48 \%$ belong to a specific breed (31 of 65), according to with the statistical analysis it exists a statistically significant association $(\mathrm{P}=0.0061)$ among Mestizo patients and CDV, Mestizo breed presents a RR OF 1.79 and $2.66(\mathrm{OR})$ more times the possibility to contract the disease (table 3 ).

Regarding the season year effect over the presence of $\mathrm{CDV}$, it was determined that $45 \%$ of the cases were presented during the winter, $23 \%$ in the spring, $18 \%$ in summer and $14 \%$ during the fall being the winter the season statistically associated $(\mathrm{P}=0.0165)$ with the presence of $\mathrm{CDV}$, for winter it was calculated an RR of 1.81 and 2.47 (OR) more times the possibility that during this season patients were infected by CDV (table 4).

\section{Discussion}

Once carried out the CDV epidemiologic study, it was determined a prevalence rate of 9 cases for every 1000 patients into the VH under study, which is located in Pachuca de Soto City. Related to the association variables it was determined that the gender, vaccine or not vaccine applications, age, breed and season year, they can make a canine more or less susceptible to contract and develop the disease, regarding the gender it was observed a higher incidence in males (63\%) than in females (37\%), data that agree with that reported by GonzálezChávez et $\mathrm{al}^{11}$ who reported an incidence of $67 \%$ and $33 \%$ in males and females respectively, according to with Soto et al12, it exists a higher prevalence in males, due to them ambulatory habit, which favors contact between infected individuals, increasing the exposition and therefore the infection risk.
On the other hand, the vaccine application is a practice that can lead to decrease the risk to contract the virus, since it was observed a $61 \%$ in disease presentation frequency is not vaccinated dogs, a situation similar to that shown by González-Chávez et $\mathrm{al}^{11}$, who reported a presentation frequency of 95\%, according to with Sykes $^{3}$, an opportune immunization is the key for the prevention of the infection caused by CDV, nevertheless, according to with obtained data in the present study this practice is not carried out.

Age is a determining factor in the presentation of $\mathrm{CDV}$, in the present study it was determined a higher prevalence in those individuals under 6 months, according to with described by Martella et al ${ }^{13}$, puppies become more susceptible due maternal antibodies decrease, while older individuals are protected by immunization via vaccination, nevertheless it is possible cases occurring. In a study carried out by Almuna $^{14}$, it was shown that as age increase the number of seropositive dogs increases too, which coincides with that reported by Lechner et $\mathrm{al}^{15}$, who mention that it exists a higher risk to contract the disease according to individuals age increases, due to the individual has more time to be exposed to the virus and become naturally infected.

Despite the existence of reports, which indicate a high presentation frequency in pure breed canines, in this study it was reported that Mestizo breed individuals had a $52 \%$ presentation frequency, similar to that reported by González-Chávez et al11, who reported a $43 \%$ presentation frequency in Mestizo breed canines.

Respect to disease seasonality, according to the reported by Ettinger \& Feldman ${ }^{16}$ and Martella et $\mathrm{al}^{13}$, the presentation degree for this disease is higher during fall and winter, similar to that reported in the present study. 
$\mathrm{CDV}$ is an infectious disease with a high prevalence of the VH understudy, males and individuals under 7 months are the most affected, as well as the Mestizo breed dogs, the disease occurs more frequently during the winter. Animals without vaccines are the most affected, although an important percentage of vaccinated animals presented the disease.

\section{Conflicts of interest}

Authors declare that they have no potential conflicts of interest regarding the research, authorship, and / or publication of this article.

\section{Acknowledgments}

To the veterinary hospital "Petterra" for providing the medical records of the patients admitted during the period 2017-2018.

\section{Literature cited}

1. Céspedes PF, Cruz P, Navarro CO. Modulation of immune response during canine distemper virus infection: terapeutic and vaccine development implications. Arch Med Vet 2010;42(2):14.28. DOI: https://doi.org/10.4067/S0301-732X201000 $\underline{0200003}$

2. Pinotti MA. Distemper Canino: evaluación de dos alternativas terapéuticas y caracterización de aspectos clínico-epidemiológicos en la ciudad de Santa Fe, durante los años 1998-2009 [tesis maestría]. [Santa Fe]. Universidad Nacional del Litoral; 2009 [citado 20 de mayo de 2019]. Recuperado a partir de: https://bibliotecavirtual. unl. edu.ar:8443/handle/11185/323

3. Sykes JE. Canine Distemper Virus Infection. In: Canine and Feline Infectious Diseases: Elsevier; 45
2014. p. 152-65. DOI: https://doi. org/10.1016/ C2009-0-41370-9

4. Bravo Webber LC, Escalante Chavez D. Estudio retrospectivo del Distemper canino en animales llegados al hospital universitario de veterinaria (ciudad de Santa Cruz de la Sierra, quinquenio 2002-2006) [tesis licenciatura]. [Santa Cruz]. Universidad Autónoma Gabriel René Moreno; 2007 [citado 20 de octubre de 2019]. Recuperado a partir de http://190.186.110.75/ sistemabibliotecario/ doc_tesis/TESIS\%20LUIS\%20CAR LOS \%20BRAVO-20101104-100837.pdf

5. Ettinger SJ, Feldman EC, editores. Tratado de medicina interna veterinaria: 6ta edición. Madrid: Elsevier; 2007.

6. Ralston SH, Afzal MA, Helfrich MH, Fraser WD, Gallagher JA, Mee A, et al. Multicenter blinded analysis of RT-PCR detection methods for paramyxoviruses in relation to Paget's disease of bone. J Bone Miner Res 2007;22(4):569-77. https://doi.org/10.1359/jbmr.070103

7. Selby PL, Davies M, Mee AP. Canine distemper virus induces human osteoclastogenesis through NF-kappaB and sequestosome 1/P62 activation. J Bone Miner Res 2006;21(11):1750-6. https://doi. org/10.1359/jbmr.070103

8. Costa VGD, Saivish MV, Rodrigues RL, Lima Silva RF, Moreli ML, Kruger RH. Molecular and serological surveys of canine distemper virus: A meta-analysis of cross-sectional studies. PloS one 2019;14(5):1-19

https://doi.org/10.1371/journal.pone.0217594

9. Martelab [Internet]. Madrid. Test de Distemper canino (virus del moquillo); 2019 [citado 23 de mayo de 2019]. Recuperado a partir de: https: //materlab.com/index.php?id product=790

$\&$ controller=product\&id_lang=1 
10.Xunta de Galicia [Internet]. OPS. EPIDAT 3.1. Coruña A. Washington DC. Xunta de Galicia; 2006 [citado 20 diciembre de 2019]. Recuperado a partir de: http://dxsp.sergas.es/ApliEdatos/ Epidat/ Ayuda/12-Ayuda\%20Jerarquizacion.pdf

11.González Chávez MT, Peraza González B, Díaz Rodríguez S, Camacho Socarrás C, Vega Rodríguez N, Vega Cañizares E. Caracterización clínica del moquillo canino en dos municipios de La Habana. Rev Salud Anim 2017;39(1): 43-50.

12. Soto A, Luna LR, Rosadio R, Maturrano L, Detección molecular del virus del distemper canino en casos clínicos de caninos domésticos no vacunados y determinación de los factores de riesgo. Rev Investig Vet Peru 2018; 29(3):964-71. DOI: https://doi.org/10.15381/rivep.v29i3. 14744

13. Martella V, Elia G, Buonavoglia C. Canine distemper virus. Vet Clin Small Anim 2008;38(4):787-97. DOI: https://doi.org/10.1016 /j.cvsm.2008.02.007
14.Almuna R. Factores de riesgo asociados a tasas de infeccion de distemper canino en perro doméstico (Canis familiaris) y carnívoros silvestres de la reserva de la biósfera de Janos, Chihuahua, México 2016. https://doi.org/10. 13140/RG.2.2.1 $\underline{7882.54722}$

15.Lechner ES, Crawford PC, Levy JK, Edinboro $\mathrm{CH}$, Dubovi EJ, Caligiuri R. Prevalence of protective antibody titers for canine distemper virus and canine parvovirus in dogs entering a Florida animal shelter. J Am Vet Med Assoc 2010;236(12):1317-21. https://doi.org/10.2460/ javma.236.12.1317

16.Ettinger SJ, Feldman EC, editores. Tratado de medicina interna veterinaria Vol II. Enferme dades del perro y del gato. 4ta edicion. Buenos Aires: Intermedica; 1997. p. 470-84.

Nota del Editor:

Journal of the Selva Andina Animal Science (JSAAS) se mantiene neutral con respecto a los reclamos jurisdiccionales publicados mapas y afiliaciones institucionales. 